\title{
Persistent Electrical Activity in Primary Nociceptors after Spinal Cord Injury Is Maintained by Scaffolded Adenylyl Cyclase and Protein Kinase A and Is Associated with Altered Adenylyl Cyclase Regulation
}

\author{
Alexis Bavencoffe, ${ }^{1 *}$ Yong Li, ${ }^{1 *}$ Zizhen Wu, ${ }^{1}$ Qing Yang, ${ }^{1}$ Juan Herrera, ${ }^{2}$ Eileen J. Kennedy, ${ }^{3} \odot$ Edgar T. Walters, ${ }^{1}$ \\ and $\mathbb{C O C a r m e n ~ W . ~ D e s s a u e r ~}^{1}$ \\ Departments of ${ }^{1}$ Integrative Biology and Pharmacology and ${ }^{2}$ Diagnostic and Interventional Imaging, McGovern Medical School at UTHealth, Houston, \\ Texas 77030, and ${ }^{3}$ Department of Pharmaceutical and Biomedical Sciences, College of Pharmacy, University of Georgia, Athens, Georgia 30602
}

Little is known about intracellular signaling mechanisms that persistently excite neurons in pain pathways. Persistent spontaneous activity (SA) generated in the cell bodies of primary nociceptors within dorsal root ganglia (DRG) has been found to make major contributions to chronic pain in a rat model of spinal cord injury (SCI) (Bedi et al., 2010; Yang et al., 2014). The occurrence of SCI-induced SA in a large fraction of DRG neurons and the persistence of this SA long after dissociation of the neurons provide an opportunity to define intrinsic cell signaling mechanisms that chronically drive SA in pain pathways. The present study demonstrates that SCI-induced SA requires continuing activity of adenylyl cyclase (AC) and cAMP-dependent protein kinase (PKA), as well as a scaffolded complex containing AC5/6, A-kinase anchoring protein 150 (AKAP150), and PKA. SCI caused a small but significant increase in the expression of AKAP150 but not other AKAPs. DRG membranes isolated from SCI animals revealed a novel alteration in the regulation of AC. AC activity stimulated by $\mathrm{Ca}^{2+}$-calmodulin increased, while the inhibition of AC activity by $\mathrm{G} \alpha$ i showed an unexpected and dramatic decrease after SCI. Localized enhancement of the activity of AC within scaffolded complexes containing PKA is likely to contribute to chronic pathophysiological consequences of SCI, including pain, that are promoted by persistent hyperactivity in DRG neurons.

Key words: A-kinase anchoring protein; chronic pain; cAMP; DRG; hyperexcitability; spontaneous activity

Significance Statement

Chronic neuropathic pain is a major clinical problem with poorly understood mechanisms and inadequate treatments. Recent findings indicate that chronic pain in a rat SCI model depends upon hyperactivity in dorsal root ganglia (DRG) neurons. Although cAMP signaling is involved in many forms of neural plasticity, including hypersensitivity of nociceptors in the presence of inflammatory mediators, our finding that continuing cAMP-PKA signaling is required for persistent SA months after SCI and long after isolation of nociceptors is surprising. The dependence of ongoing SA upon AKAP150 and AC5/6 was unknown. The discovery of a dramatic decrease in G $\alpha$ i inhibition of AC activity after SCI is novel for any physiological system and potentially has broad implications for understanding chronic pain mechanisms.

\section{Introduction}

The mechanisms that maintain chronic pain after injury to either the peripheral or CNS are poorly understood, and these neuro-

\footnotetext{
Received March 7, 2015; revised Dec. 22, 2015; accepted Dec. 23, 2015.

Author contributions: A.B., E.T.W., and C.W.D. designed research; A.B., Y.L., Z.W., Q.Y., and J.H. performed research; E.J.K. and C.W.D. contributed unpublished reagents/analytic tools; A.B., Y.L., Z.W., Q.Y., E.T.W., and C.W.D. analyzed data; A.B., E.T.W., and C.W.D. wrote the paper.

This work was supported by National Institutes of General Medical Sciences Grant GM60419 to C.W.D., Neurological Diseases and Stroke Grant NS091759 to C.W.D. and E.T.W., and Department of Defense USAMRAA W81XWH12-1-0504 to E.T.W.

The authors declare no competing financial interests.
}

pathic pain mechanisms are inadequately targeted by available therapeutics (Cohen and Mao, 2014). Permanent, intractable pain is often produced by spinal cord injury (SCI) (Finnerup, 2013; Walters, 2014). Surprisingly, persistent pain-related behavior that develops in rats after contusive SCI at the thoracic level

\footnotetext{
${ }^{*}$ A.B. and Y.L. contributed equally to this study.

Correspondence should be addressed to either Dr. Carmen W. Dessauer or Dr. Edgar T. Walters, Department of Integrative Biology and Pharmacology, University of Texas Medical School at Houston, 6431 Fannin Street, Houston TX 77030, E-mail: Carmen.W.Dessauer@uth.tmc.edu or Edgar.T.Walters@uth.tmc.edu. DOI:10.1523/JNEUROSCI.0895-15.2016

Copyright $@ 2016$ the authors $\quad 0270-6474 / 16 / 361660-09 \$ 15.00 / 0$
} 
requires chronic, ongoing electrical activity in primary afferent neurons. This was shown by the reversal of behavioral measures of spontaneous and evoked pain produced by knocking down a voltage-gated $\mathrm{Na}^{+}$channel, Nav1.8, which is uniquely expressed in primary afferent neurons and required for nociceptor SA (Yang et al., 2014). SCI-induced chronic SA is especially prominent in the somata of C-fiber dorsal root ganglia (DRG) neurons, where it has been observed both in vivo and in small dissociated DRG neurons months after injury (Bedi et al., 2010). Most of the DRG neurons with SA after SCI are nociceptors as indicated by their small size and frequent expression of TRPV1 and Nav1.8 channels (Bedi et al., 2010; Wu et al., 2013; Yang et al., 2014). Given the strong evidence that SA generated in the somata of nociceptors contributes to chronic pain after SCI, it is important to define the mechanisms that persistently maintain this SA.

Persistent activity in the adenylyl cyclase (AC)-cAMP-protein kinase A (PKA) pathway has been suggested as a mechanism to maintain hyperexcitability in nociceptors for days or weeks after peripheral inflammation or injury (Aley and Levine, 1999; Liao et al., 1999; Song et al., 2006; Villarreal et al., 2009), but whether ongoing CAMP signaling contributes to pain-related hyperexcitability lasting months or longer in neuropathic conditions is unknown. Moreover, possible roles for macromolecular complexes that coordinate cAMP-dependent events, the nature of complexes that might be linked to nociceptor SA, and whether molecular regulation within the complexes is altered in nociceptors during any chronic pain conditions are unknown. Taking advantage of the fact that the SCI-induced SA that has been linked to chronic pain is retained in nociceptor somata after dissociation (Bedi et al., 2010; Wu et al., 2013; Yang et al., 2014), we demonstrate that chronic SA in nociceptors requires continuing activity of AC and PKA, plus the presence of an intact complex of AC5/6, PKA, and the scaffolding molecule A-kinase anchoring protein 150 (AKAP150, also called AKAP79 in humans or AKAP5). These findings plus novel alterations found in the regulation of $\mathrm{AC}$ after SCI provide new insights into basic mechanisms that maintain SA in nociceptors and the consequent excitation of pain pathways.

\section{Materials and Methods}

All procedures complied with guidelines of the International Association for the Study of Pain and were approved by the institutional animal care and use committee. Male rats (200-300 g) were maintained under a 12:12 h reversed light/dark cycle, and experiments were performed during the dark phase (Bedi et al., 2010).

SCI procedures. Contusion injury and postsurgical care were conducted as described previously (Bedi et al., 2010). Briefly, rats in the SCI group were deeply anesthetized with ketamine $(80 \mathrm{mg} / \mathrm{kg})$, xylazine $(20$ $\mathrm{mg} / \mathrm{kg})$, and acepromazine $(0.75 \mathrm{mg} / \mathrm{kg})$ before laminectomy of $\mathrm{T} 10$ vertebrae followed by a spinal impact using an Infinite Horizon impactor (150 kdyne, $1 \mathrm{~s}$ dwell time). Animals in the Sham group received identical surgery without spinal impact. Animals in the Naive group received no surgery. All SCI animals exhibited Basso, Beattie, and Bresnahan (BBB) hindlimb motor scores of 0-1 (Basso et al., 1995) $1 \mathrm{~d}$ after SCI. Hindlimb motor function showed only partial recovery when examined before excision of DRGs 1-6 months after SCI, similar to that described previously (Bedi et al., 2010; Yang et al., 2014).

Dissociation and culture of DRG neurons. Selected DRGs (L4, L5) were minced and incubated for $40 \mathrm{~min}$ at $34^{\circ} \mathrm{C}$ with trypsin $(0.3 \mathrm{mg} / \mathrm{ml})$ and collagenase D $(1.5 \mathrm{mg} / \mathrm{ml})$. DRG fragments were triturated, the neurons were plated without serum or growth factors onto $8 \mathrm{~mm}$ glass coverslips coated with poly-L-ornithine, and kept overnight in DMEM $<5 \% \mathrm{CO}_{2}$, $95 \%$ humidity at $37^{\circ} \mathrm{C}$.

Recording from dissociated DRG neurons. Whole-cell patch recordings of SA were made at $\sim 23^{\circ} \mathrm{C}$ from small neurons (soma diameter $\leq 30 \mu \mathrm{m}$ and input capacitance $\leq 45 \mathrm{pF}) 18-28 \mathrm{~h}$ after dissociation using a MultiClamp 700B amplifier (Molecular Devices) as described previously (Bedi et al., 2010; Wu et al., 2013). Patch pipettes were pulled from borosilicate glass capillaries with a P-97 puller (Sutter) and fire polished to achieve a final electrode resistance of 3-8 $\mathrm{M} \Omega$. Pipettes were filled with solution containing the following (in $\mathrm{mM}$ ): $134 \mathrm{KCl}, 1.6 \mathrm{MgCl}_{2}, 13.2$ $\mathrm{NaCl}, 3$ EGTA, 9 HEPES, $1 \mathrm{Mg}$-ATP, and $0.3 \mathrm{Na}-\mathrm{GTP}$ (pH 7.2 adjusted with $\mathrm{KOH}, 300 \mathrm{mOsM}$, adjusted with sucrose). The bath solution contained $140 \mathrm{NaCl}, 3 \mathrm{KCl}, 1.8 \mathrm{CaCl}_{2}, 2 \mathrm{MgCl}_{2}, 10 \mathrm{HEPES}$, and 10 glucose (pH 7.4 adjusted with $\mathrm{NaOH}$, osmolarity $320 \mathrm{mOsM}$ ). After forming a tight seal $(>1 \mathrm{G} \Omega)$, the membrane was ruptured. After whole-cell configuration was established under voltage clamp, the input capacitance was measured, and then capacitance and series resistance were electronically compensated. The calculated liquid junction potential was $4.3 \mathrm{mV}$ and was not corrected. Spontaneous activity (SA) was measured in current-clamp mode, beginning 2 min after membrane rupture. In previous studies, we defined SA as at least 1 spike occurring within $60 \mathrm{~s}$ (i.e., minimum firing rate of $0.02 \mathrm{~Hz}$ ) (Bedi et al., 2010). Because a demonstration of inhibitory effects on SA is impractical in cells with very low firing rates, in the current study we selected for neurons having initial SA firing rates of $0.1-5 \mathrm{~Hz}$. For in vitro superfusion of DRG neurons with inhibitory or inactive control agents, solutions were driven by gravity from a set of independent tubes connected to an array of fused silica columns (inner diameter, $200 \mu \mathrm{m}$ ). Rapid exchange of solutions was achieved by shifting the columns horizontally with a micromanipulator. The distance from the column mouth to the recorded cell was $\sim 100 \mu \mathrm{m}$. A subset of neurons was recorded with the perforated patch method to achieve stable recordings for much longer periods. Recordings were made with gramicidin $(50 \mu \mathrm{g} / \mathrm{ml})$ in the recording pipette following established procedures (Wu et al., 2013; Zhu et al., 2014). The PKA inhibitors, $N$-[2-(p-bromocinnamylamino)ethyl]-5-isoquinolinesulfonamide dihydrochloride (H-89), Rp-cAMPs, and the AC inhibitor 2' deoxyadenosine $3^{\prime}$-monophosphate ( $2^{\prime}$ deoxy-3'AMP) were purchased from Sigma-Aldrich. The AKAP disrupting peptide stHt 31 and its control stHt31P were purchased from Promega. Electrophysiological data were analyzed using PatchMaster, Clampfit version 10.4 (Molecular Devices) and Origin 5.0 (MicroCal Software).

Antibodies used for immunoprecipitation and Western blotting. These were mouse or rabbit anti-AKAP150 (EMD Millipore for Western blotting and Santa Cruz Biotechnology for immunoprecipitation) (Hoshi et al., 2003), mouse anti-AKAP12 (Sigma-Aldrich, clone JP74) (Havekes et al., 2012), mouse anti-PKA RII $\beta$ (BD Transduction Laboratories) (Hoshi et al., 2003), mouse anti- $\beta$-actin (Santa Cruz Biotechnology), and normal mouse or rabbit IgG (Santa Cruz Biotechnology). The mouse antiAC5 hybridoma cell lines were generated by Genscript against human AC5 peptide CGNQVSKEMKRMGFEDPKDKN (Hu et al., 2009). Antibodies were purified by affinity chromatography using antigen immobilized peptide and are highly selective for AC5 over AC6 (data not shown).

$R T-P C R$ of AC isoforms. Fresh DRGs or RNA later-stabilized DRGs were homogenized on ice using a conventional rotor-stator homogenizer (RNase-free). Total RNA was extracted using RNeasy Mini Kit (QIAGEN) according to the protocol suggested by the manufacturer. The RNA was eluted with RNase-free water and quantitated using the NanoDrop 1000 spectrophotometer. First-strand cDNA was generated from DNase-treated total RNA (250 ng-600 ng) using Moloney murine leukemia virus reverse transcriptase (New England Biolabs) and oligo(dT) primers. qRT-PCR was performed using an Eppendorf Mastercycler ep realplex ${ }^{2}$ (Eppendorf) in the presence of SYBR Green I. Primers to rat AC isoforms 1-9 (Table 1) and rat GAPDH as the control were designed with NCBI Primer-Blast or using published sequences (Bek et al., 2001; Landa et al., 2005). The $10 \mathrm{ng}$ cDNA template was used in each reaction, performed in triplicate for each primer set. The cycling conditions were as follows: $2 \mathrm{~min}$ at $94^{\circ} \mathrm{C}$ followed by 40 cycles of $15 \mathrm{~s}$ at $94^{\circ} \mathrm{C}$, $0.5 \mathrm{~min}$ at $60^{\circ} \mathrm{C}$, and $0.5 \mathrm{~min}$ at $72^{\circ} \mathrm{C}$. The fold change in transcript levels $\left(2^{\Delta \Delta \mathrm{Ct}}\right)$ between SCI and Sham control samples was calculated from the cycle times $\left(\mathrm{C}_{\mathrm{t}}\right)$ of each primer set as follows, where $\Delta \Delta \mathrm{Ct}=\Delta \mathrm{Ct}$ $\left(\mathrm{ACX}_{\mathrm{SCI}}-\mathrm{GAPDH}_{\mathrm{SCI}}\right)-\Delta \mathrm{ct}\left(\mathrm{ACX}_{\text {Sham }}-\mathrm{GAPDH}_{\text {Sham }}\right)$. Statistical analysis was performed according to Rieu and Powers (2009). Amplified PCR products were run on $1.5 \%$ agarose gels after $35-40$ cycles. Products 
Table 1. Primers to rat AC isoforms 1-9

\begin{tabular}{|c|c|c|c|c|}
\hline$A C$ isoform & Primer & Sequence & Position GenBank & $\begin{array}{l}\text { Product } \\
\text { size (bp) }\end{array}$ \\
\hline \multirow[t]{2}{*}{$\mathrm{AC1}$} & Sense & 5'-TCCCCGGAACATGGATCTCT-3' & $2415-2434$ & \multirow[t]{2}{*}{481} \\
\hline & Antisense & $5^{\prime}$-CCCAGTGCTATCCATCCGAC-3' & $2895-2876$ & \\
\hline \multirow[t]{2}{*}{$\mathrm{AC2}$} & Sense & 5'-CTCCATTCCGGACTTCAAGG-3' & $2739-2758$ & \multirow[t]{2}{*}{268} \\
\hline & Antisense & 5'-CAGGGCATATGCAAACTCCA-3' & $3006-2987$ & \\
\hline \multirow[t]{2}{*}{$\mathrm{AC} 3$} & Sense & $5^{\prime}$-GTCACCTTAGTCACGAGAGC-3' & $4359-4378$ & \multirow[t]{2}{*}{184} \\
\hline & Antisense & $5^{\prime}$-AGTAGCAAAGGCGACTGTAG-3' & $4542-4523$ & \\
\hline \multirow[t]{2}{*}{ AC4 } & Sense & $5^{\prime}-\mathrm{GGAAGACGAGAAGGGCACCGAGAG-3^{ \prime }}$ & $1502-1525$ & \multirow[t]{2}{*}{467} \\
\hline & Antisense & 5'-GAGCTGGGGGCCTGGTTGTCAC-3' & $1968-1947$ & \\
\hline \multirow[t]{2}{*}{$\mathrm{AC5}$} & Sense & $5^{\prime}$-ACCAAGGCCACACTCAACTAC-3' & $2255-2275$ & \multirow[t]{2}{*}{163} \\
\hline & Antisense & 5'-GGTTCATCTTGGCGATCA-3' & $2417-2400$ & \\
\hline \multirow[t]{2}{*}{$\mathrm{AC6}$} & Sense & $5^{\prime}-\mathrm{CAAAGGAAGGGACGCCGAGAGG-3^{ \prime }}$ & $3731-3752$ & \multirow[t]{2}{*}{391} \\
\hline & Antisense & 5'-GGCAAATGGAAACATTCCCCTG-3' & $4122-4101$ & \\
\hline \multirow[t]{2}{*}{$\mathrm{AC7}$} & Sense & 5'-CGTTCCCGGACTTCAAAGTGT-3' & $2712-2731$ & \multirow[t]{2}{*}{355} \\
\hline & Antisense & 5'-AATCACTCCAGCAATCACAGG-3' & $3066-3046$ & \\
\hline \multirow[t]{2}{*}{$\mathrm{AC} 8$} & Sense & 5'-CAGTCTGGGCCTGAGGAAATT-3' & $2748-2768$ & \multirow[t]{2}{*}{478} \\
\hline & Antisense & 5'-AAGTCAGGTTCTTCAAGGGTA-3' & $3225-3205$ & \\
\hline \multirow[t]{2}{*}{$\mathrm{AC} 8^{\prime}$} & Sense & 5'-TTCACTTGAGCCTAGCCTCG-3' & $1363-1382$ & \multirow[t]{2}{*}{627} \\
\hline & Antisense & $5^{\prime}$-GGATGTAGATGCGGTGGAAC-3' & 1989-1970 & \\
\hline \multirow[t]{2}{*}{ AC9 } & Sense & 5'-CGGTCTCCCACAGATGAGAT-3' & $3856-3875$ & \multirow[t]{2}{*}{351} \\
\hline & Antisense & $5^{\prime}-\mathrm{TCTGGGGACAGAAACTGAGG-3^{ \prime }}$ & $4206-4187$ & \\
\hline \multirow[t]{2}{*}{ GAPDH } & Sense & 5'-TATGACAACTCCCTCAAGAT-3' & $483-502$ & \multirow[t]{2}{*}{317} \\
\hline & Antisense & 5'-AGATCCACAACGGATACATT-3' & 799-780 & \\
\hline
\end{tabular}

for AC6 and AC8 were detected by agarose gels upon longer cycles and also with alternate primers $\left(\mathrm{AC}^{\prime}\right) ; \mathrm{AC} 1$ and $\mathrm{AC} 4$ product levels were very low, and AC7 was below the level of detection for qRT-PCR. All primers were confirmed using rat brain tissue.

Immunoprecipitation of AC activity. DRGs below the vertebral T10 injury level from sham or SCI rats were used for all biochemical assays. Previous work showed similarly high incidence of SA after SCI in small neurons from DRGs from just above the injury level (T8, T9), at the injury level (T10, T11, T12), and below the injury level (L3 to L6) (Bedi et al., 2010; unpublished observations). Thus, to maximize the amount of relevant DRG tissue, we pooled DRGs bilaterally from T12 to L6. Immunoprecipitation of protein complexes with rabbit IgG (control) or anti-AKAP150 antibodies was performed as described previously (Piggott et al., 2008; Kapiloff et al., 2009; Efendiev et al., 2013). Disrupting peptides (10-20 $\mu \mathrm{M})$ were added during homogenization and were prepared as described previously (Efendiev et al., 2010). Immunoprecipitations were assayed for associated AC activity upon stimulation with $100 \mathrm{nM}$ GTP $\gamma \mathrm{S}-\mathrm{G} \alpha$ s and $50 \mu \mathrm{M}$ forskolin for $10 \mathrm{~min}$ at $37^{\circ} \mathrm{C}$. AC8 activity was measured upon stimulation with $100 \mu \mathrm{M} \mathrm{Ca}{ }^{2+}$ and $300 \mathrm{~nm}$ calmodulin. Acetylated cAMP was detected by enzyme immunoassay (ELISA kit from Enzo Life Sciences).

$A C$ activity in DRG membranes. Freshly isolated DRGs were rinsed with PBS and resuspended in sucrose supplemented buffer: $20 \mathrm{~mm}$ HEPES, 1 mм EDTA, 2 mм $\mathrm{MgCl}_{2}$, 1 mм DTT, $250 \mathrm{~mm}$ sucrose, and protease inhibitors ( $0.1 \mathrm{~mm}$ phenylmethylsulfonyl fluoride, $0.1 \mathrm{~mm} \mathrm{N \alpha -}$ p-tosyl-L-lysine chloromethyl ketone, and $0.1 \mathrm{~mm} \mathrm{~N}$-tosyl-L-phenyl alanine chloromethyl ketone). Tissue was homogenized using a rotor-stator tissue homogenizer ( $5 \mathrm{~mm}$ probe; $3 \mathrm{~s}$ pulses on ice, 7 times) and centrifuged at $1800 \times g$ to pellet nuclei. Membranes were subjected to centrifugation for $20 \mathrm{~min}$ at $60,000 \times g$, resuspended in sucrose supplemented buffer, and analyzed for protein concentration by Bradford assay. Membranes $(6-10 \mu \mathrm{g} /$ reaction) were immediately assayed for AC activity upon stimulation with the indicated reagents (Dessauer, 2002). Heart membranes were prepared from Naive/Sham or SCI animals as described above for DRGs, except that flash frozen tissue was rapidly thawed and quartered before homogenization. Membranes from Sf9 cells expressing AC1 or AC5 were prepared as described previously (Dessauer, 2002).

Statistical analysis. Data are presented as mean \pm SEM. Comparisons were made with paired or unpaired $t$ tests, one-way ANOVA followed by Bonferroni's post hoc tests corrected for multiple comparisons, or twoway ANOVA with repeated measures. SA incidence was compared using Fisher's exact tests. In many of the biochemical studies, specific a priori predictions based on published or unpublished pilot studies were tested between selected pairs of groups using $t$ tests. Each group used for biochemical comparisons included at least three experiments, with each experiment performed in duplicate or triplicate. Statistical analyses were performed with Prism 6 (Graphpad Software).

\section{Results}

Activity of anchored PKA is required for persistent SCIinduced SA in DRG neuron somata

We first asked whether continuing PKA activity is required for the maintenance of SCI-induced SA in small DRG neurons. SA occurs in the somata of numerous nociceptors at and below the injury level for at least half a year after thoracic spinal contusion, and its incidence is correlated with pain-related behavior (Bedi et al., 2010). Importantly, SCI-induced nociceptor SA is abolished by interventions that reverse behavioral signs of pain (Wu et al., 2013; Yang et al., 2014). As we found previously, SCI significantly increased the incidence of L4/L5 neurons with SA (Fig. 1A) compared with neurons in Naive or Sham groups (Fig. 1B, top bars): increased SA was found both $3 \mathrm{~d}$ after SCI (SA in 11 of 14 neurons, 79\%) and 1-6 months after SCI (23 of 32 neurons, 72\%). No significant differences in SA incidence were found between neurons tested $3 \mathrm{~d}$ versus $1-6$ months after SCI in any of the SCI groups, regardless of treatment after dissociation, so early and late test data were combined for each group (more than half of each group shown was tested 1-6 months after SCI). The increase in SA incidence after SCI was associated with significant depolarization of resting membrane potential (RMP) (Fig. 1B, bottom bars) (see also Bedi et al., 2010).

Previous work implicated ongoing PKA activity in the maintenance of hyperexcitability of small DRG neuron cell bodies (Song et al., 2006; Zheng et al., 2007) and in the induction of one type of hyperalgesic priming (Araldi et al., 2015a,b). We found that bath application of Rp-cAMPS $(100 \mu \mathrm{M}$, applied at least 30 min before establishing whole-cell configuration) significantly decreased the incidence of SA in DRG neurons dissociated from DRG in SCI animals, and tended to hyperpolarize RMP (Fig. $1 A, B)$. To determine whether a PKA inhibitor would also reduce ongoing SA from a dissociated DRG neuron, we superfused a more membrane-permeant inhibitor, H-89 (50 $\mu \mathrm{M})$, over individual cells beginning 2-4 min after establishing whole-cell configuration. As shown in Figure 1, $C$ and $D$, spontaneous discharge in the small DRG neurons we sampled was irregular and showed considerable variability within and between cells (see also Bedi et al., 2010). SA firing rates tended to increase during the first minute of whole-cell recording and then stabilize. $\mathrm{H}-89$ applied when firing had stabilized $(n=6)$ produced a decrease in firing rate within $40 \mathrm{~s}$, and SA was essentially eliminated after 2 min of superfusion. Little or no recovery occurred within 3-5 min of washout ( $n=4$, data not shown). Two-way ANOVA with repeated measures revealed significant effects of time after superfusion $\left(F_{(12,168)}=2.53 ; p=0.0044\right), 50 \mu \mathrm{M} \mathrm{H}-89$ treatment $\left(F_{(1,14)}=5.51 ; p=0.0341\right)$, and their interaction $\left(F_{(12,168)}=\right.$ $2.59 ; p=0.0035)$. Identical experiments using $10 \mu \mathrm{M} \mathrm{H}-89$ under whole-cell patch recording conditions $(n=3)$ failed to reduce SA within 5 min (data not shown). Because membrane-permeant PKA antagonists such as H-89 are typically bath applied at least $10 \mathrm{~min}$ before electrophysiological recording, and it is difficult to maintain cell health for 10 min or more with the whole-cell patch configuration, we used the much less damaging (but more technically difficult) perforated patch method to test the possibility that the lower $10 \mu \mathrm{M}$ concentration of $\mathrm{H}-89$ would suppress SA if allowed more time to penetrate into the cell. In small DRG neu- 
A
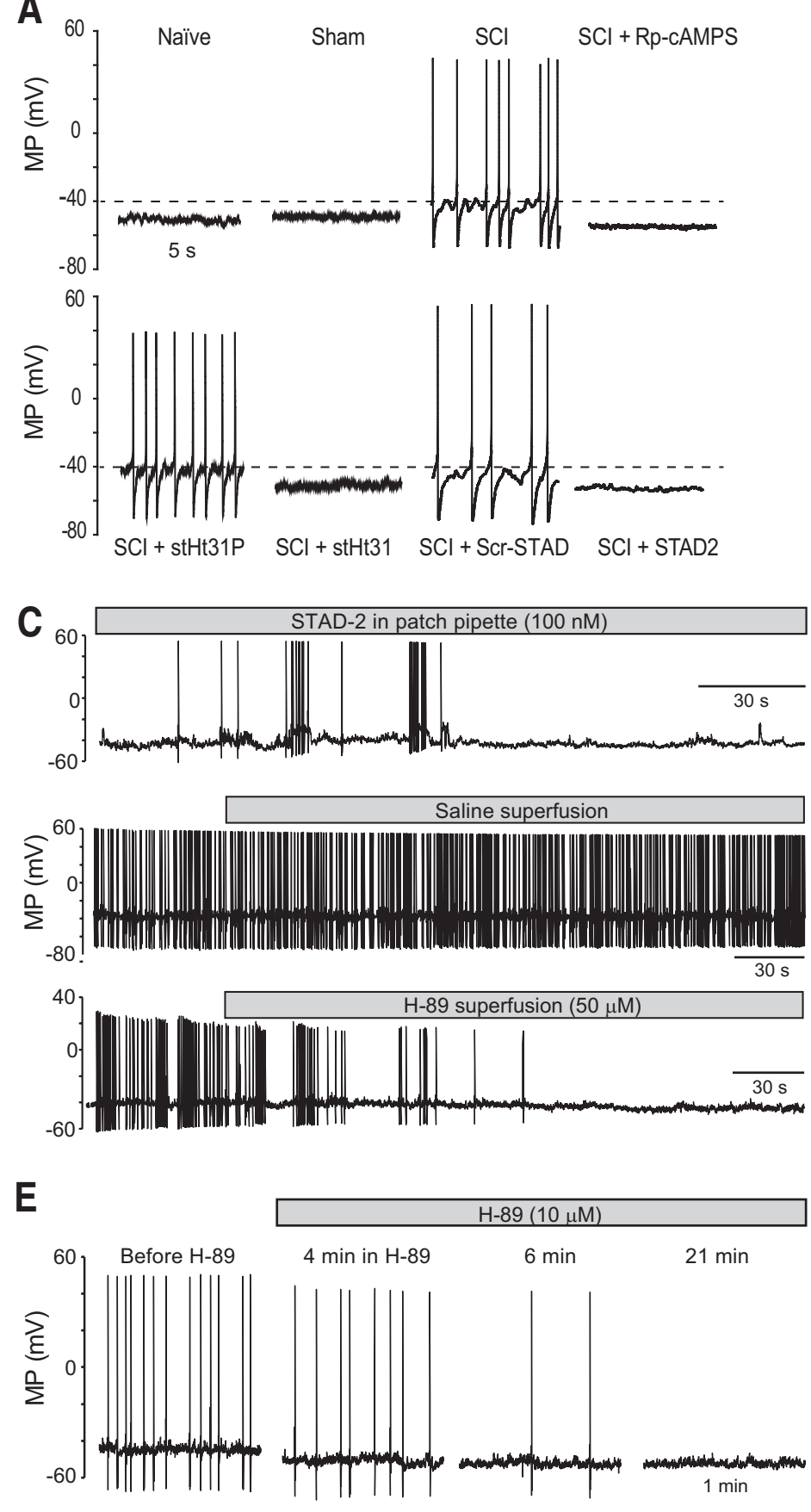
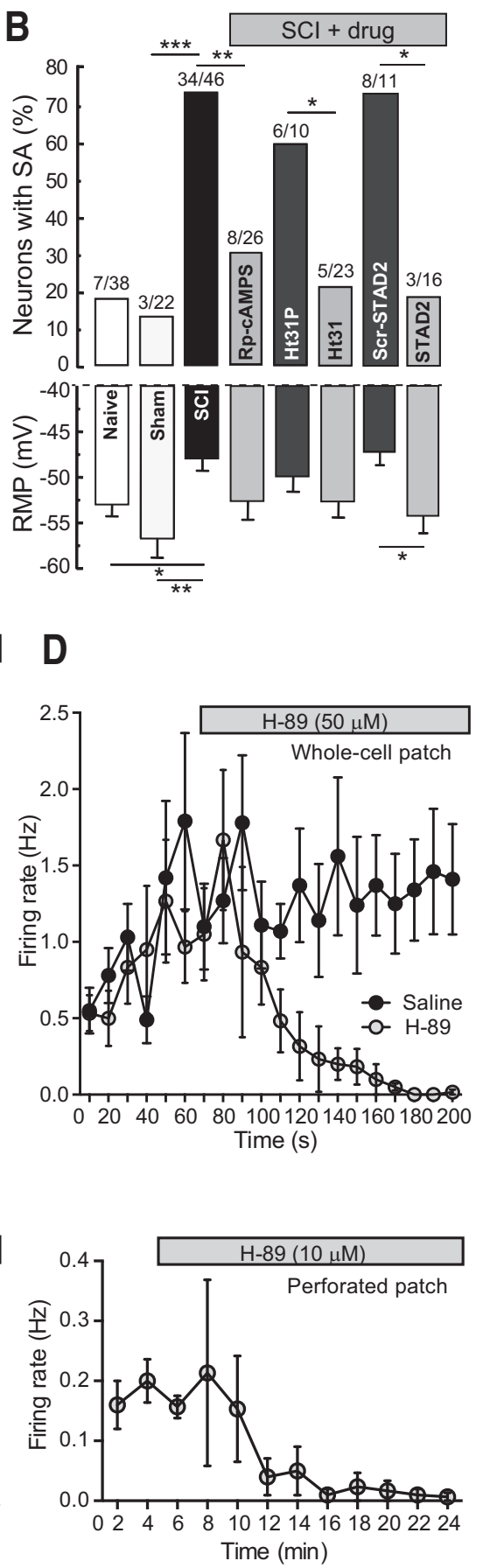

Figure 1. Anchored PKA activity maintains SCl-induced SA in dissociated small L4/L5 DRG neurons. A, Examples of SA and RMP after the indicated treatments. Dashed line indicates least negative acceptable RMP $(-40 \mathrm{mV})$ for sampled neurons. $\boldsymbol{B}$, Attenuation of SCl-induced SA and depolarized RMP by inhibitors of PKA and AKAP function. The ratio above each bar denotes the number of neurons with SA/the number of neurons sampled. Statistical comparisons of SA incidence were made with Fisher's exact tests on the indicated pairs of groups (paired experiments were run on the same batches of neurons in different coverslips on the same day). Comparisons of RMP (mean \pm SEM) were made with one-way ANOVA followed by Bonferroni post hoc tests: ${ }^{*} p<0.05$; ** $p<$ $0.01 ;{ }^{* * *} p<0.001$. C, Examples of ongoing SA in dissociated DRG neurons and its rapid reduction by inhibitors of PKA and AKAP function. Top, Cell recorded under whole-cell configuration with a higher resistance patch pipette containing $100 \mathrm{~nm}$ STAD-2 in pipette solution. Middle, Cell recorded with lower resistance patch pipette and superfused with saline (same as bath solution). Bottom, Cell recorded with a lower resistance pipette and superfused with $\mathrm{H}-89$ in bath solution. $D$, Time course of the effects of superfused $50 \mu \mathrm{m}$ H- 89 on SA firing rate (mean \pm SEM). Two-way ANOVA revealed significant effects of $\mathrm{H}-89$ treatment ( $n=6$ neurons) versus controls $(n=10)$ and of time after treatment. $E$, Prolonged recordings of dissociated DRG neurons with the perforated patch method shows that $10 \mu \mathrm{m}$ H-89 eventually suppresses ongoing SA. Left, Examples of SA recorded 1 min before and at the indicated times after superfusion of $10 \mu \mathrm{m} H-89$. Right, Time course of the effects of $10 \mu \mathrm{m} \mathrm{H}-89$ treatment on mean SA firing rate recorded with perforated patch. Each point represents the mean \pm SEM $(n=3$ cells) of the average spike frequency in each cell during the indicated 2 min period. MP, Membrane potential (includes action potentials).

rons showing stable perforated patch recordings for long periods (25-75 min, $n=3$ ), $10 \mu \mathrm{M} \mathrm{H}-89$ produced clear, prolonged suppression of SA within 5-10 min of extracellular application (Fig. 1E).
PKA is often targeted to signaling complexes by specific binding to AKAPs. We tested the necessity of this interaction by using a stearated AKAP-PKA disrupting peptide, stHt 31 , to inhibit the interaction between AKAPs and the regulatory subunits of PKA. 
A

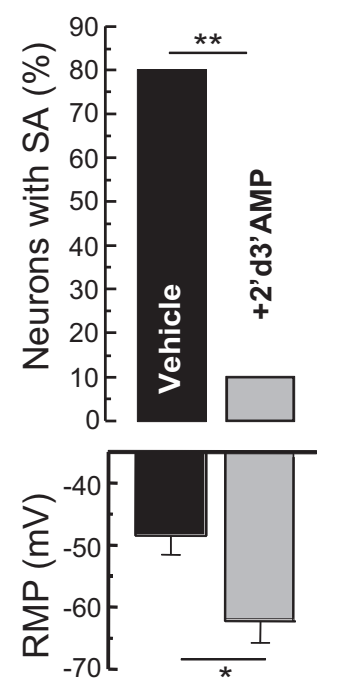

B

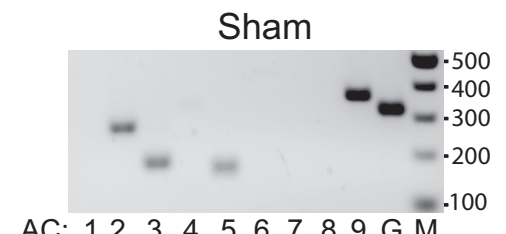

AC: $123 \quad 3 \quad 4 \quad 5 \quad 67889$ G M

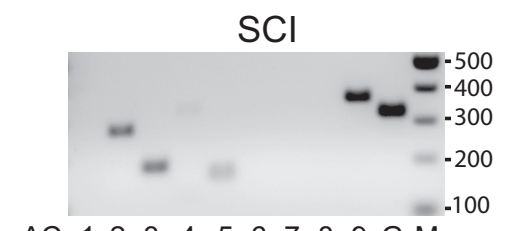

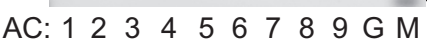

C

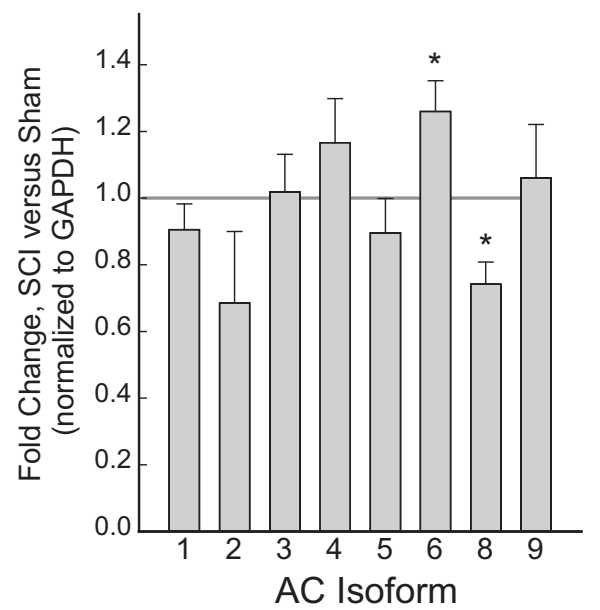

Figure 2. AC activity maintains SCI-induced SA.A, Attenuation of SCI-induced SA and depolarized RMP by an AC inhibitor (2' deoxy-3'AMP). The proportion of neurons exhibiting SA was analyzed with Fisher's exact test $\left({ }^{* *} p<0.01 ; 10\right.$ cells per group); RMP analyzed with unpaired $t$ test $\left({ }^{*} p<0.05\right)$. B, Agarose gel of RT-PCR products from RNA isolated from Sham and SCI rats of AC isoforms and GAPDH control after 40 cycles. Primers used are indicated in Table 1. C, qRT-PCR of AC isoform expression in DRGs from Sham and SCl rats. Fold change (2 $\left.{ }^{\Delta \Delta C t}\right)$ after SCl \pm SD is plotted. All samples were normalized to GAPDH controls ( $n=3$, performed in triplicate). For description of statistical analysis, see Materials and Methods.

Intracellular dialysis of stHt31 $(50 \mu \mathrm{M})$ through the pipette (in the whole-cell patch configuration) into neurons isolated from SCI animals significantly reduced the incidence of neurons displaying SA, whereas an inactive version of this peptide, stHt31P $(50 \mu \mathrm{M})$, had no effect (Fig. $1 A, B)$. As a complementary approach, we used STAD-2, a stable "hydrocarbon-stapled" PKAAKAP disrupting peptide that is highly selective for the RII regulatory subunit of PKA (Wang et al., 2014). Intracellular delivery of STAD-2 (500 nM) significantly reduced SA incidence and hyperpolarized the RMP, compared with effects of the scrambled inactive version, Scr-STAD (Fig. $1 A, B$ ).

For both stHt 31 and STAD-2, the inhibitory effects were very rapid. The cells lacking SA exhibited no SA at any point during the recording session, even at the onset (30-60 s after establishing whole-cell configuration). Moreover, the few cells with SA did not show a progressive decrease in firing rate after breaking into the cell. These observations suggest that, at these concentrations and with the 30-60 s delay between break-in and recording onset, the inhibitors had an all-or-none effect on recorded SA. To observe the development of the predicted inhibition of ongoing SA, we used a lower concentration of inhibitor applied through a smaller aperture patch pipette. We found 4 neurons that exhibited SA when recordings began 15-30 s after break-in using a patch pipette containing $100 \mathrm{nM}$ STAD-2 (instead of $500 \mathrm{~nm}$ ) and having a resistance of $7-12 \mathrm{M} \Omega$ (instead of 3-6 $\mathrm{M} \Omega$ ). In each case, the early SA was abolished within $100 \mathrm{~s}$ of break-in, as illustrated in Figure $1 C$, and no further SA occurred for the remainder of the recordings (2-10 $\mathrm{min}$ of inactivity). These results confirm that ongoing SA observed in small dissociated DRG neurons after SCI is blocked by disruption of AKAP-PKA interactions.

Interestingly, even at the higher concentrations used in most of our recordings, neither STAD-2 nor stHT31 completely eliminated SA in the sampled populations. Indeed, the SA incidence in the presence of these inhibitors was about the same as in cells sampled from Naive and Sham groups (Fig. 1B). Moreover, neither inhibitor caused the DRG neurons to become inexcitable; artificial injection of depolarizing current in the presence of ei- ther inhibitor was still able to evoke action potentials (data not shown). Together, these results indicate that ongoing activity of PKA anchored by the RII subunit to an AKAP is continuously required for the generation of persistent $\mathrm{SA}$ in isolated nociceptors induced by prior SCI, but this activity is not required for normal excitability.

\section{AC5/6 complexed with AKAP150 is required for persistent SCI-induced SA}

The requirement of anchored PKA activity for persistent SCIinduced SA implied that AC activity is also necessary. Using intracellular dialysis of the AC P-site inhibitor, 2'deoxy-3'AMP $(300 \mu \mathrm{M})$, we found significant reduction of SA incidence and significant hyperpolarization in small sensory neurons from SCI rats compared with neurons dialyzed with vehicle (Fig. $2 A$ ). To obtain a complete profile of $\mathrm{AC}$ isoform expression, we used qRT-PCR to compare DRG transcript levels between Sham and SCI groups. Largely in accord with previous studies (Ehnert et al., 2004), AC2, AC3, AC5, and AC9 were detected in DRGs taken from T12 to L6 segments and, to a lesser extent, AC6 and AC8 (Fig. 2B). Relatively small differences in RNA levels for any AC isoform were found between SCI and Sham groups, although AC6 was significantly elevated and AC8 was significantly reduced in the SCI preparations (Fig. 2C).

Most small DRG neurons that exhibit SA after SCI express TRPV1 (Wu et al., 2013). In nociceptors, TRPV1 is complexed with AKAP150 and AC5 and/or AC6 (Efendiev et al., 2013). Therefore, we probed this complex using an AC-AKAP150 disrupting peptide that is selective for the AC5/6 binding domain of AKAP150 (AKAP79 ${ }^{77-153}$, hereafter called AC-AKAPi) (Efendiev et al., 2010, 2013). We have previously shown that AC-AKAPi is selective for AC5/6 and does not displace AC2 or AC9 from the AKAP79/150 scaffold (Efendiev et al., 2010). AC3 and AC8 activity can also be immunoprecipitated with AKAP150 when overexpressed in HEK293 cells (Fig. 3A) (Efendiev et al., 2010). AC-AKAPi $(10 \mu \mathrm{M})$ had no effect on AKAP150 anchoring of AC3 or AC8 but disrupted AC5 interactions with the scaffold (Fig. 

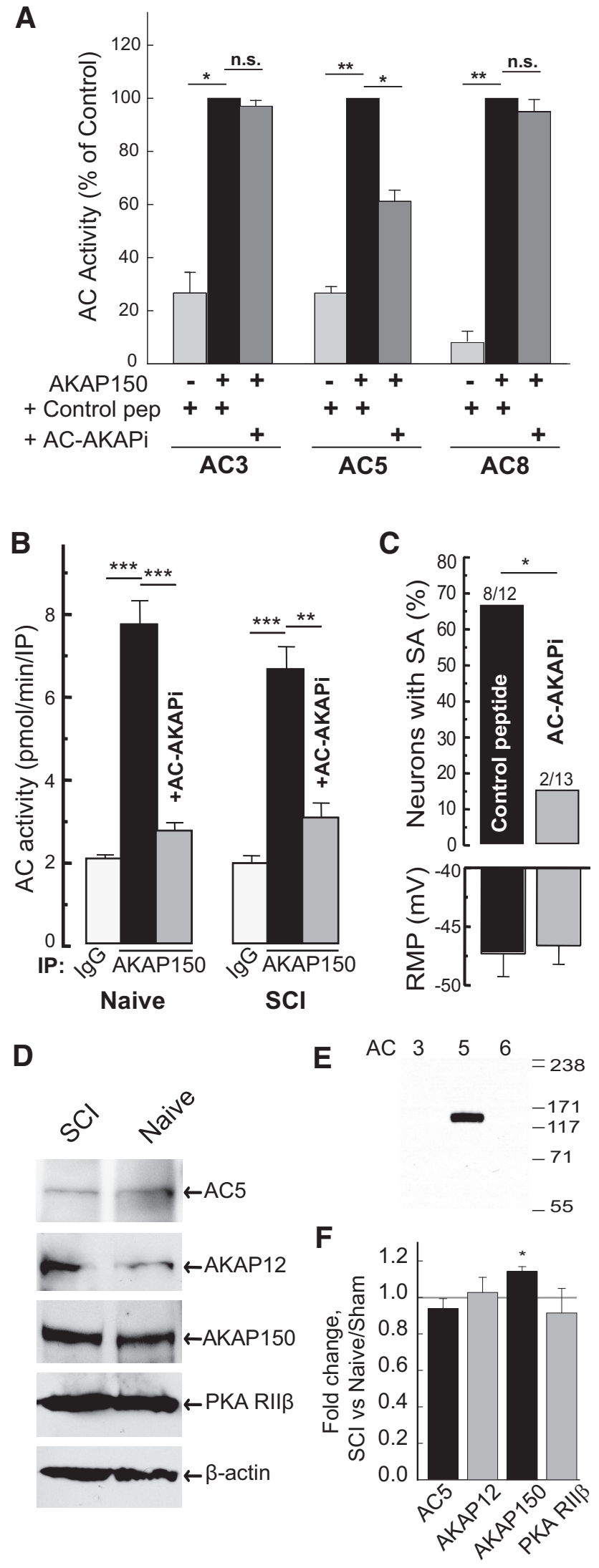

Figure 3. Disruption of AKAP150-anchored AC in DRGs by an AC5/6-AKAP150-selective disrupting peptide (AC-AKAPi) attenuates $S C$-induced $S A$. $A, A C-A K A P i$ is selective for $A C 5$ and does not disrupt association of AC3 or AC8 with AKAP150. HEK293 cells were transfected with AKAP150 and the indicated AC isoforms. Samples were immunoprecipitated with antiAKAP150 in the presence of control or disrupting peptides (10 $\mu \mathrm{m})$ during cell lysis, and the
$3 A$ ). Our control peptide (AKAP79 ${ }^{109-290}$ ) had no effect on the association of any AC isoform with AKAP79/150 (Fig. 3A) (Efendiev et al., 2010). To determine the level of AC activity associated with AKAP150 in SCI and Naive animals, we immunoprecipitated AKAP150, using IgG as a control, from lysates of DRGs taken from segments T12 to L6 followed by G $\alpha$ s/forskolin-stimulated AC activity measurements. Antibodies against AKAP150 pulled down nearly fourfold increased AC activity compared with IgG in preparations from both $\mathrm{SCI}$ and Naive groups (Fig. 3B). The disrupting peptide AC-AKAPi $(20 \mu \mathrm{M})$ significantly reduced AKAP150-associated AC activity obtained from both Naive and SCI groups (Fig. 3B). As AC-AKAPi is selective for AC5 and AC6, and does not affect interactions of AKAP150 with other AC isoforms (Fig. 3A) (Efendiev et al., 2010), these results indicate that most of the AC activity associated with AKAP150 in DRGs is produced by AC5/6.

To investigate the requirement of this complex for the maintenance of SCI-induced SA, we dialyzed small sensory neurons isolated from SCI rats with AC-AKAPi $(20 \mu \mathrm{M})$ or a control peptide, AKAP150 ${ }^{109-290}(20 \mu \mathrm{M})$, that does not affect AC-AKAP150 interactions. As found with the PKA-AKAP disrupting peptides, dialysis with AC-AKAPi caused a significant decrease in SA incidence compared with the control peptide (Fig. $3 C$ ), albeit with no apparent effect on RMP. This result strengthens the conclusion that AC5/6-AKAP150 interactions are required for persistent nociceptor SA.

Previous studies have identified expression of several AKAPs in nociceptors, including AKAP150, AKAP12 (also known as Gravin), AKAP18, and Yotiao (Schnizler et al., 2008). Western blotting confirmed expression of AKAP150, AKAP12, and the RII $\beta$ subunit of PKA in DRGs, but the protein levels were largely unchanged after SCI (Fig. 3D). A small but significant increase in AKAP150 was detected after SCI. AC5 protein levels were also unchanged (Fig. 3D); limited amounts of DRG tissue and inadequate quality of antibodies to other AC isoforms prevented detection of other $\mathrm{AC}$ isoforms.

\section{SCI alters the regulation of ACs in DRGs}

An important question is whether SCI alters the function of the AC5/6-AKAP150-PKA complex. A persistent functional change in this complex could be important for driving chronic SA and consequent pain. To begin to address this question, we looked for SCI-induced modifications in the regulation of AC activity in membranes isolated from DRGs taken from T12 to L6 segments in control (Naive and Sham) and SCI rats. AC activity measurements were made under basal enzyme conditions, during stimulation with purified GTP $\gamma$ S-bound G $\alpha$ s (100 nM) either in the presence or absence of GTP $\gamma S-G \alpha \mathrm{i}(1 \mu \mathrm{M})$, and upon stimulation with $\mathrm{Ca}^{2+}$ /calmodulin (100 $\mu \mathrm{m} / 300 \mathrm{~nm}$; Fig. 4A). Membranes from Naive $(n=2)$ and Sham $(n=2)$ rats showed identical response patterns, so these control data were pooled. Previous

\footnotetext{
$\leftarrow$

associated stimulated $\mathrm{AC}$ activity was measured (mean $\pm \mathrm{SEM}, n=3$ performed in duplicate, normalized to control peptide with AKAP150). ${ }^{*} p<0.05$ (paired $t$ test on non-normalized data). ${ }^{* *} p<0.01$ (paired $t$ test on non-normalized data). $B$, AKAP150-associated AC activity is reduced by AC-AKAPi in DRGs from sham and SCI rats. Samples were immunoprecipitated with control lg or anti-AKAP150 in the presence or absence of AC-AKAPi $(20 \mu \mathrm{M})$, and associated AC activity was measured (mean $\pm S E M, n=3$ ). ${ }^{* * *} p<0.001$ (unpaired $t$ test). C, Attenuation of SCI-induced SA by AC-AKAPi. * $p<0.05$ (Fisher's exact test). $\boldsymbol{D}, \boldsymbol{F}$, AKAP150, but not AC5, protein expression in DRGS is slightly enhanced by SCI (mean \pm SEM, $n=3-5$ ). ${ }^{*} p<0.05$ (paired $t$ test of $S C$ v v Sham controls). $E$, Characterization of anti-AC5. WB of membranes from Sf9 cells expressing $A C 3, A C 5$, or AC6. n.s., Not significant.
} 
A

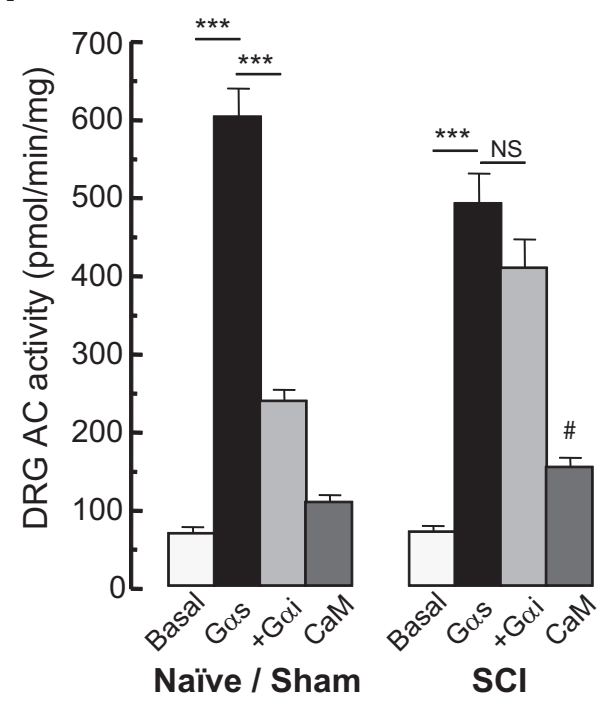

B

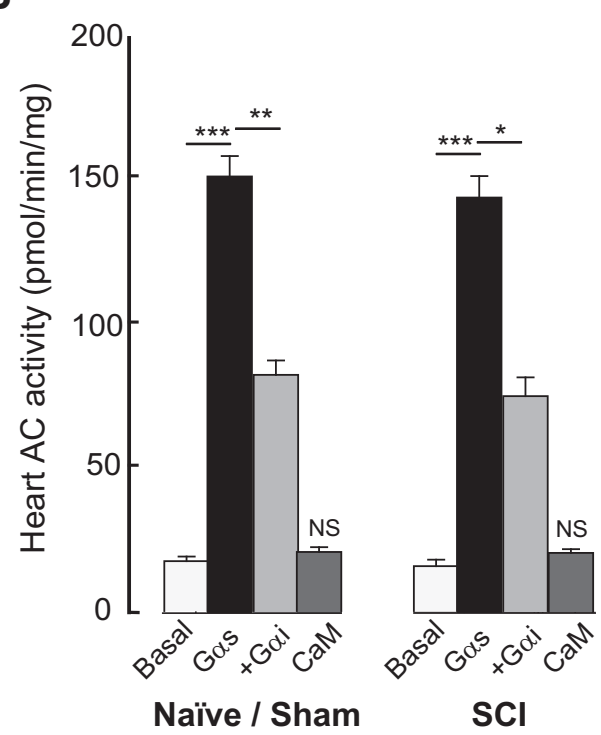

C

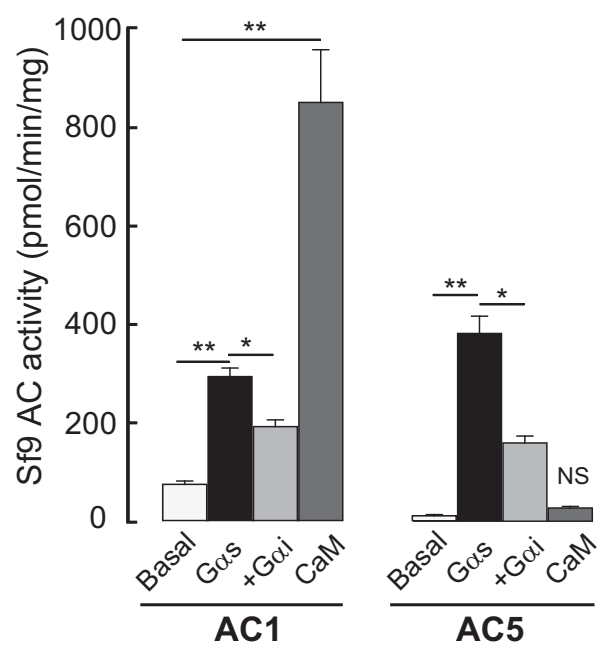

Figure 4. $\mathrm{SCl}$ reduces $\mathrm{G} \alpha \mathrm{i}$ inhibition of $\mathrm{AC}$ activity in DRG membranes and increases $\mathrm{Ca}^{2+} /$ calmodulin-stimulated activity without changing basal or total $G \alpha s$-stimulated AC activity. AC activity was measured in membranes prepared from $(\boldsymbol{A}) \operatorname{DRGs}(n=4),(\boldsymbol{B})$ heart $(n=3)$, or $(\boldsymbol{C})$ Sf9 cells expressing $\mathrm{AC} 1$ or $\mathrm{AC} 5(n=3)$ under basal conditions or in the presence of $\mathrm{G} \alpha \mathrm{s}$ studies have failed to find significant differences in nociceptor physiology or pain-related behavior between Naive and Sham animals (Bedi et al., 2010; Wu et al., 2013; Yang et al., 2014). Gos produced an eightfold increase in activity, which was inhibited $60 \%$ by the presence of $\mathrm{G} \alpha \mathrm{i}$. This pattern indicates major contributions from AC5/6, which are activated by $\mathrm{G} \alpha$ s, inhibited by $\mathrm{G} \alpha \mathrm{i}$, and unaffected by $\mathrm{Ca}^{2+} /$ calmodulin. Stimulation by $\mathrm{Ca}^{2+} /$ calmodulin alone caused a 1.5 -fold enhancement of basal AC activity, suggesting weak contributions from AC1, AC3, and/or AC8.

Importantly, DRG membranes isolated from SCI animals $(n=4)$ showed significant differences in AC regulation compared with membranes from the control animals; there was a dramatic loss of G $\alpha$ i inhibition and a 1.5-fold increase in AC activity stimulated by $\mathrm{Ca}^{2+} /$ calmodulin (Fig. $4 A$ ). SCI had no significant effect on the total basal or G $\alpha$ s-stimulated AC activity. This alteration in AC regulation after SCI was not a generalized effect of SCI, as no alterations in G $\alpha$ i inhibition or $\mathrm{Ca}^{2+} /$ calmodulin stimulation were detected in heart tissue from SCI groups compared with Naive/Sham groups (Fig. 4B). Examples of AC regulatory patterns are shown as controls in Figure $4 C$, where membranes from Sf9 cells expressing AC1 or AC5 were assayed under the same regulatory conditions as above. Although both $\mathrm{AC}$ isoforms were inhibited by $\mathrm{G} \alpha \mathrm{i}(35 \%$ and $58 \%$ for $\mathrm{AC} 1$ and AC5, respectively), only $\mathrm{AC} 1$ (and AC8, data not shown) was activated by $\mathrm{Ca}^{2+} /$ calmodulin (10-fold). These findings suggest that SCI-induced alterations in the regulation of ACs, especially AC5/6, are important for driving PKA activity and promoting nociceptor SA.

\section{Discussion}

This study has revealed a previously unsuspected role for AC5 and/or AC6 complexed with AKAP150 and PKA in maintaining nociceptor hyperactivity after SCI, and has disclosed novel alterations of AC function that have not been reported previously in any physiological context.

Increases in cAMP synthesis in primary afferent neurons have long been known to participate in various responses to bodily injury, including axonal regeneration (Siddiq and Hannila, 2015) and sensitization (Gold and Gebhart, 2010). In nociceptors, increased cAMP synthesis contributes to sensitization by inflammatory signals lasting several hours (e.g., Taiwo et al., 1989; Cui and Nicol, 1995; Hingtgen et al., 1995; Kress et al., 1996; Gold et al., 1998), and the acute sensitization of nociceptors by heat or prostaglandin $\mathrm{E}_{2}$ depends upon AKAP150-PKA complexes (Jeske et al., 2008; Schnizler et al., 2008; Efendiev et al., 2013; Fischer and McNaughton, 2014). Surprisingly few studies have investigated whether AC-PKA signaling also contributes to the maintenance of persistent hyperexcitability of nociceptors. Inhibitors of PKA activation or AC activity can reduce nociceptor hyperexcitability when applied days or weeks after nerve crush (Liao et al., 1999), peripheral prostaglandin $\mathrm{E}_{2}$ injection (Aley and Levine, 1999; Villarreal et al., 2009), or "chronic" (1-2 weeks) compression of lumbar DRGs (CCD model) (Song et al., 2006; Zheng et al., 2007; Huang et al., 2012). Inhibition of PKA activity by H- 89 has been reported to block the induction of hyperalgesic priming (lasting several weeks) by agonists of mu opioid receptors (Araldi et al.,

(100 nm), G $\alpha$ s plus G $\alpha \mathrm{i}(1 \mu \mathrm{m})$, or Ca ${ }^{2+} /$ calmodulin (CaM; $\left.100 \mu \mathrm{m} / 300 \mathrm{~nm}\right) .{ }^{*} p<0.05$ (unpaired $t$ tests). ${ }^{* *} p<0.01$ (unpaired $t$ tests). ${ }^{* * *} p<0.001$ (unpaired $t$ tests). "Significant difference in CaM-stimulated AC responses of $\mathrm{SCl}$ versus Naive/Sham animals. NS, Not significant. 
2015a) or adenosine A1 receptors (Araldi et al., 2015b). However, in these priming models, PKA activity only appeared to contribute for several days to the maintenance of the primed state, and it is unknown whether the reported behavioral alterations are driven by nociceptor hyperexcitability or SA. In contrast, we found that inhibition of PKA activation by Rp-cAMPS, disruption of PKA anchoring to AKAPs, or inhibition of AC activity by 2'deoxy-3'AMP eliminated both the SA and depolarization of RMP in small DRG neurons observed months after SCI. In addition, the PKA inhibitor H-89 was found to rapidly abolish SA months after SCI. Dependence of nociceptor hyperexcitability on AC-cAMP-PKA signaling in the CCD model has been associated with increased expression of PKA, including RII $\beta$ (Huang et al., 2012), which we did not find after SCI. A major difference between our SCI model and most neuropathic pain models, such as CCD, is that most of the sensory neurons tested in the SCI model are probably not damaged by the neuropathic insult (Bedi et al., 2010). Moreover, unlike in the CCD model (Huang et al., 2012), sensory neuron hyperexcitability recorded after SCI does not depend upon activation of protease-activated receptor 2 (Q. Yang and E. Walters, unpublished observations). The present study shows, for the first time in any pain model, that AC activity is necessary to maintain nociceptor hyperexcitability months after the initiating event. This demonstration is particularly noteworthy because the AC-dependent ongoing SA occurs in the same sensory neurons whose persistent hyperactivity has been shown to be necessary for behavioral signs of chronic pain after SCI (Yang et al., 2014).

The displacement of AC5/6 from the AKAP 150 complex by a selective disrupting peptide (AC-AKAPi) strongly reduced SA, providing clear evidence that SCI-induced SA depends upon signaling activity in a complex containing AC5/6, PKA, and AKAP150, all of which are present in DRGs from naive and SCI rats. This finding is interesting in light of the dramatic deficits in behavioral measures of nociception and neuropathic pain found in AC5 null mutant mice (Kim et al., 2007). While those deficits were assumed to reflect loss of AC5 function in the CNS, the present results suggest that loss of AC5 function in primary nociceptors could have contributed to the results reported by Kim et al. (2007).

We found no increase in expression of PKA and only a small increase in expression of AKAP150 after SCI. In contrast, we found a dramatic change in the regulation of AC activity. Two regulatory alterations occurred after SCI. First, there was a $\sim 50 \%$ increase in the relatively small amount of AC activity stimulated by $\mathrm{Ca}^{2+}$ /calmodulin. In principle, this could contribute to hyperexcitability and is consistent with either increased expression or increased sensitivity of AC1, AC3, or AC8. AC1 contributes to chronic pain mechanisms in the brain (Vadakkan et al., 2006) but was not detected in DRGs (Fig. 2B) (Ehnert et al., 2004). AC8 in the spinal cord and brain has been suggested to contribute to persistent pain (Wei et al., 2002) and binds AKAP150 (Efendiev et al., 2010; Willoughby et al., 2010), but AC8 would represent a small fraction of AKAP150-associated AC in DRGs, even after SCI. Importantly, the function of numerous AKAP150anchored channels is known to be either enhanced (e.g., Cav1.2, Cav3.2, TRPV1, and TRPV4) or inhibited (KCNQ and TREK) by PKA (Fischer and McNaughton, 2014), and any of these or yet to be identified channels associated with AKAP150 may promote nociceptor SA.

Second and perhaps more important, there was a large and novel effect of SCI on the regulation of AC activity by Gai: the strong inhibitory effect of $\mathrm{G} \alpha \mathrm{i}$ on $\mathrm{G} \alpha$ s-stimulated AC activity observed in naive animals was nearly eliminated after SCI. This loss of inhibition also is likely to contribute in vivo to increased $\mathrm{AC}$ activity and maintenance of nociceptor SA. The altered regulation of ACs in DRG membranes after SCI differs from the sensitization of AC5/6 that occurs following prolonged stimulation of $\mathrm{G} \alpha_{\mathrm{i} / \mathrm{o}}$-coupled receptors by opioids (Watts and Neve, 2005) because we found no increase in total G $\alpha$ s-stimulated activity. The altered regulation occurs at the level of the AC, and thus differs from the G $\alpha$ i-dependent nociceptor mechanism proposed for chronic hyperalgesia in which stress or inflammation may switch the coupling of some receptors from $\mathrm{G} \alpha$ s (leading to $\mathrm{PKA}$ activation) to $\mathrm{G} \alpha \mathrm{i}$ (leading to $\mathrm{PKC} \varepsilon$ activation) (Khasar et al., 2008). Instead, SCI causes a loss of G $\alpha$ i inhibition of AC activity. This might, in principle, be caused by a change in the relative protein expression of different AC isoforms. However, the only significant changes in relative mRNA levels for AC isoforms after SCI were an increase in AC6 and decrease in AC8. If these changes were translated into corresponding changes in protein levels, one would expect increased rather than decreased inhibition by $\mathrm{G} \alpha \mathrm{i}$, as AC6 is one of the AC isoforms most sensitive to G $\alpha$ i inhibition (Taussig et al., 1994; Chen-Goodspeed et al., 2005). Instead, it is likely that SCI causes intrinsic modification of AC5/ 6 that reduces its inhibition by G $\alpha \mathrm{i}$. An interesting question is whether, in addition to contributing to the maintenance of chronic nociceptor hyperactivity in conditions such as SCI, loss of G $\alpha$ i inhibition of AC might contribute to the PKA-dependent ("Type II") hyperalgesic priming that can be produced by repeated peripheral stimulation of G $\alpha \mathrm{i}$ (Araldi et al., 2015a,b). The unexpected chronic alterations of AC regulation are consistent with SCI-induced reprogramming of numerous, uninjured nociceptors into a persistent, hyperactive cellular state that was proposed (Bedi et al., 2010; Walters, 2012) and then validated (Yang et al., 2014) as a major contributor to chronic pain. While the actual contributions of altered AC regulation to behavioral measures of pain after SCI (and potentially other pain conditions) have yet to be determined and the molecular mechanisms underlying the alteration of $\mathrm{AC}$ regulation remain to be defined, the present results provide the first direct demonstration that persistent hyperactivity of sensory neurons that excite pain pathways is associated with long-lasting alterations of AC function and regulation in the hyperactive neurons.

\section{References}

Aley KO, Levine JD (1999) Role of protein kinase A in the maintenance of inflammatory pain. J Neurosci 19:2181-2186. Medline

Araldi D, Ferrari LF, Levine JD (2015a) Repeated mu-opioid exposure induces a novel form of the hyperalgesic priming model for transition to chronic pain. J Neurosci 35:12502-12517. CrossRef Medline

Araldi D, Ferrari LF, Levine JD (2015b) Adenosine-A1 receptor agonist induced hyperalgesic priming type II. Pain. Advance online publication. Retrieved Nov. 14, 2015. Medline

Basso DM, Beattie MS, Bresnahan JC (1995) A sensitive and reliable locomotor rating scale for open field testing in rats. J Neurotrauma 12:1-21. CrossRef Medline

Bedi SS, Yang Q, Crook RJ, Du J, Wu Z, Fishman HM, Grill RJ, Carlton SM, Walters ET (2010) Chronic spontaneous activity generated in the somata of primary nociceptors is associated with pain-related behavior after spinal cord injury. J Neurosci 30:14870-14882. CrossRef Medline

Bek MJ, Zheng S, Xu J, Yamaguchi I, Asico LD, Sun XG, Jose PA (2001) Differential expression of adenylyl cyclases in the rat nephron. Kidney Int 60:890-899. CrossRef Medline

Chen-Goodspeed M, Lukan AN, Dessauer CW (2005) Modeling of Galpha(s) and Galpha(i) regulation of human type V and VI adenylyl cyclase. J Biol Chem 280:1808-1816. Medline

Cohen SP, Mao J (2014) Neuropathic pain: mechanisms and their clinical implications. BMJ 348:f7656. CrossRef Medline 
Cui M, Nicol GD (1995) Cyclic AMP mediates the prostaglandin E2induced potentiation of bradykinin excitation in rat sensory neurons. Neuroscience 66:459-466. CrossRef Medline

Dessauer CW (2002) Kinetic analysis of the action of P-site analogs. Methods Enzymol 345:112-126. CrossRef Medline

Efendiev R, Samelson BK, Nguyen BT, Phatarpekar PV, Baameur F, Scott JD, Dessauer CW (2010) AKAP79 interacts with multiple adenylyl cyclase (AC) isoforms and scaffolds AC5 and -6 to alpha-amino-3-hydroxyl-5methyl-4-isoxazole-propionate (AMPA) receptors. J Biol Chem 285: 14450-14458. CrossRef Medline

Efendiev R, Bavencoffe A, Hu H, Zhu MX, Dessauer CW (2013) Scaffolding by A-kinase anchoring protein enhances functional coupling between adenylyl cyclase and TRPV1 channel. J Biol Chem 288:3929-3937. CrossRef Medline

Ehnert C, Tegeder I, Pierre S, Birod K, Nguyen HV, Schmidtko A, Geisslinger G, Scholich K (2004) Protein associated with Myc (PAM) is involved in spinal nociceptive processing. J Neurochem 88:948-957. CrossRef Medline

Finnerup NB (2013) Pain in patients with spinal cord injury. Pain 154 [Suppl 1]:S71-S76.

Fischer MJ, McNaughton PA (2014) How anchoring proteins shape pain. Pharmacol Ther 143:316-322. CrossRef Medline

Gold MS, Gebhart GF (2010) Nociceptor sensitization in pain pathogenesis. Nat Med 16:1248-1257. CrossRef Medline

Gold MS, Levine JD, Correa AM (1998) Modulation of TTX-R INa by PKC and PKA and their role in PGE2-induced sensitization of rat sensory neurons in vitro. J Neurosci 18:10345-10355. Medline

Havekes R, Canton DA, Park AJ, Huang T, Nie T, Day JP, Guercio LA, Grimes Q, Luczak V, Gelman IH, Baillie GS, Scott JD, Abel T (2012) Gravin orchestrates protein kinase A and beta2-adrenergic receptor signaling critical for synaptic plasticity and memory. J Neurosci 32:18137-18149. CrossRef Medline

Hingtgen CM, Waite KJ, Vasko MR (1995) Prostaglandins facilitate peptide release from rat sensory neurons by activating the adenosine $3^{\prime}, 5^{\prime}$-cyclic monophosphate transduction cascade. J Neurosci 15:5411-5419. Medline

Hoshi N, Zhang JS, Omaki M, Takeuchi T, Yokoyama S, Wanaverbecq N, Langeberg LK, Yoneda Y, Scott JD, Brown DA, Higashida H (2003) AKAP150 signaling complex promotes suppression of the M-current by muscarinic agonists. Nat Neurosci 6:564-571. CrossRef Medline

Hu CL, Chandra R, Ge H, Pain J, Yan L, Babu G, Depre C, Iwatsubo K, Ishikawa Y, Sadoshima J, Vatner SF, Vatner DE (2009) Adenylyl cyclase type 5 protein expression during cardiac development and stress. Am J Physiol Heart Circ Physiol 297:H1776-H1782. CrossRef Medline

Huang ZJ, Li HC, Cowan AA, Liu S, Zhang YK, Song XJ (2012) Chronic compression or acute dissociation of dorsal root ganglion induces cAMPdependent neuronal hyperexcitability through activation of PAR2. Pain 153:1426-1437. CrossRef Medline

Jeske NA, Diogenes A, Ruparel NB, Fehrenbacher JC, Henry M, Akopian AN, Hargreaves KM (2008) A-kinase anchoring protein mediates TRPV1 thermal hyperalgesia through PKA phosphorylation of TRPV1. Pain 138: 604-616. CrossRef Medline

Kapiloff MA, Piggott LA, Sadana R, Li J, Heredia LA, Henson E, Efendiev R, Dessauer CW (2009) An adenylyl cyclase-mAKAPbeta signaling complex regulates cAMP levels in cardiac myocytes. J Biol Chem 284: 23540-23546. CrossRef Medline

Khasar SG, Burkham J, Dina OA, Brown AS, Bogen O, Alessandri-Haber N, Green PG, Reichling DB, Levine JD (2008) Stress induces a switch of intracellular signaling in sensory neurons in a model of generalized pain. J Neurosci 28:5721-5730. CrossRef Medline

Kim KS, Kim J, Back SK, Im JY, Na HS, Han PL (2007) Markedly attenuated acute and chronic pain responses in mice lacking adenylyl cyclase-5. Genes Brain Behav 6:120-127. CrossRef Medline

Kress M, Rödl J, Reeh PW (1996) Stable analogues of cyclic AMP but not cyclic GMP sensitize unmyelinated primary afferents in rat skin to heat stimulation but not to inflammatory mediators, in vitro. Neuroscience 74:609-617. CrossRef Medline

Landa LR Jr, Harbeck M, Kaihara K, Chepurny O, Kitiphongspattana K, Graf O, Nikolaev VO, Lohse MJ, Holz GG, Roe MW (2005) Interplay of $\mathrm{Ca}^{2+}$ and cAMP signaling in the insulin-secreting MIN6 beta-cell line. J Biol Chem 280:31294-31302. CrossRef Medline
Liao X, Gunstream JD, Lewin MR, Ambron RT, Walters ET (1999) Activation of protein kinase A contributes to the expression but not the induction of long-term hyperexcitability caused by axotomy of Aplysia sensory neurons. J Neurosci 19:1247-1256. Medline

Piggott LA, Bauman AL, Scott JD, Dessauer CW (2008) The A-kinase anchoring protein Yotiao binds and regulates adenylyl cyclase in brain. Proc Natl Acad Sci U S A 105:13835-13840. CrossRef Medline

Rieu I, Powers SJ (2009) Real-time quantitative RT-PCR: design, calculations, and statistics. Plant Cell 21:1031-1033. CrossRef Medline

Schnizler K, Shutov LP, Van Kanegan MJ, Merrill MA, Nichols B, McKnight GS, Strack S, Hell JW, Usachev YM (2008) Protein kinase A anchoring via AKAP150 is essential for TRPV1 modulation by forskolin and prostaglandin E2 in mouse sensory neurons. J Neurosci 28: 4904-4917. CrossRef Medline

Siddiq MM, Hannila SS (2015) Looking downstream: the role of cyclic AMP-regulated genes in axonal regeneration. Front Mol Neurosci 8:26. CrossRef Medline

Song XJ, Wang ZB, Gan Q, Walters ET (2006) cAMP and cGMP contribute to sensory neuron hyperexcitability and hyperalgesia in rats with dorsal root ganglia compression. J Neurophysiol 95:479-492. CrossRef Medline

Taiwo YO, Bjerknes LK, Goetzl EJ, Levine JD (1989) Mediation of primary afferent peripheral hyperalgesia by the cAMP second messenger system. Neuroscience 32:577-580. CrossRef Medline

Taussig R, Tang WJ, Hepler JR, Gilman AG (1994) Distinct patterns of bidirectional regulation of mammalian adenylyl cyclases. J Biol Chem 269: 6093-6100. Medline

Vadakkan KI, Wang H, Ko SW, Zastepa E, Petrovic MJ, Sluka KA, Zhuo M (2006) Genetic reduction of chronic muscle pain in mice lacking calcium/calmodulin-stimulated adenylyl cyclases. Mol Pain 2:7. CrossRef Medline

Villarreal CF, Sachs D, Funez MI, Parada CA, de Queiroz Cunha F, Ferreira SH (2009) The peripheral pro-nociceptive state induced by repetitive inflammatory stimuli involves continuous activation of protein kinase $\mathrm{A}$ and protein kinase $\mathrm{C}$ epsilon and its $\mathrm{Na}(\mathrm{V}) 1.8$ sodium channel functional regulation in the primary sensory neuron. Biochem Pharmacol 77:867877. CrossRef Medline

Walters ET (2012) Nociceptors as chronic drivers of pain and hyperreflexia after spinal cord injury: an adaptive-maladaptive hyperfunctional state hypothesis. Front Physiol 3:309. CrossRef Medline

Walters ET (2014) Neuroinflammatory contributions to pain after SCI: roles for central glial mechanisms and nociceptor-mediated host defense. Exp Neurol 258:48-61. CrossRef Medline

Wang Y, Ho TG, Bertinetti D, Neddermann M, Franz E, Mo GC, Schendowich LP, Sukhu A, Spelts RC, Zhang J, Herberg FW, Kennedy EJ (2014) Isoform-selective disruption of AKAP-localized PKA using hydrocarbon stapled peptides. ACS Chem Biol 9:635-642. CrossRef Medline

Watts VJ, Neve KA (2005) Sensitization of adenylate cyclase by Galpha i/ocoupled receptors. Pharmacol Ther 106:405-421. CrossRef Medline

Wei F, Qiu CS, Kim SJ, Muglia L, Maas JW, Pineda VV, Xu HM, Chen ZF, Storm DR, Muglia LJ, Zhuo M (2002) Genetic elimination of behavioral sensitization in mice lacking calmodulin-stimulated adenylyl cyclases. Neuron 36:713-726. CrossRef Medline

Willoughby D, Masada N, Wachten S, Pagano M, Halls ML, Everett KL, Ciruela A, Cooper DM (2010) AKAP79/150 interacts with AC8 and regulates $\mathrm{Ca}^{2+}$-dependent cAMP synthesis in pancreatic and neuronal systems. J Biol Chem 285:20328-20342. CrossRef Medline

Wu Z, Yang Q, Crook RJ, O’Neil RG, Walters ET (2013) TRPV1 channels make major contributions to behavioral hypersensitivity and spontaneous activity in nociceptors after spinal cord injury. Pain 154:2130-2141. CrossRef Medline

Yang Q, Wu Z, Hadden JK, Odem MA, Zuo Y, Crook RJ, Frost JA, Walters ET (2014) Persistent pain after spinal cord injury is maintained by primary afferent activity. J Neurosci 34:10765-10769. CrossRef Medline

Zheng JH, Walters ET, Song XJ (2007) Dissociation of dorsal root ganglion neurons induces hyperexcitability that is maintained by increased responsiveness to cAMP and cGMP. J Neurophysiol 97:15-25. CrossRef Medline

Zhu Y, Zhang XL, Gold MS (2014) Activity-dependent hyperpolarization of EGABA is absent in cutaneous DRG neurons from inflamed rats. Neuroscience 256:1-9. CrossRef Medline 